\title{
NA BUSCA DAS AMÉRICAS, NA FUGA DOS HAITIS, O SUJEITO IMIGRANTE NA LÍNGUA
}

\author{
Liana Cristina Giachini \\ Verli Petri \\ Viviane Teresinha Biacchi Brust
}

RESUMO: Neste texto, tratamos acerca do político como constitutivo da língua, articulado à noção de política linguística. Tais questóes são aqui pensadas quando destinadas aos sujeitos imigrantes, bem como em seus efeitos, em distintas condiçốes de produção: em relação ao sujeito imigrante italiano dos séculos XIX e XX, quando da Ditadura Vargas, e ao haitiano, no século XXI, quando se tem democracia e também globalização.

PALAVRAS-CHAVE: política de línguas; sujeito imigrante; língua de imigrantes.

\section{Palavras primeiras}

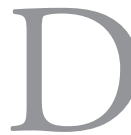

a segunda metade do século XIX, adentrando também o século XX, atraídos pela promessa de uma nova vida na América, milhares de imigrantes italianos aportaram em terras brasileiras. Em condições de produção outras, mas não dissociadas do sistema que determina a transferência de mão de obra barata, hoje, início do século XXI, milhares de imigrantes haitianos veem, no Brasil, a oportunidade de um recomeço. Em meio a essas distantes realidades no tempo e no espaço - em que consideramos haver pontos de encontro e também de derivas em relação ao próprio sentido de imigrante -, a língua se constitui como o lugar em que a historicidade se manifesta, abrindo campo para discutir a constituição desse sujeito "entrelínguas", e, nesse espaço de enunciação",

1 Embora consideremos que são diferentes as condições de produção desses acontecimentos históricos, linguísticos e discursivos, também tomamos de Guimarães (s.d.) a questão de 
encontramos as marcas do político na língua e das políticas linguísticas nesses sujeitos afetados pela língua e pela história.

Neste texto, procuramos refletir acerca do político como constitutivo da língua, articulando essa ideia à noção de política linguística, para, ao reencontrar esses conceitos, compreendê-los em sua diferença e em suas aproximaçóes. Partimos, portanto, de uma discussão teórica, à qual serão associados alguns recortes discursivos, especificamente selecionados das leis que regulamentam ou que vão determinar as políticas linguísticas - sendo que "o recorte é uma unidade discursiva" (ORLANDI, 2002, p. 14), e, por isso, oferece espaço à significação - escolhidos à guisa de elucidação. Tais recortes foram selecionados de modo a ilustrar as relaçóes entre política linguística e o político na língua e, para tanto, demarcamos como temática a questão da imigração tomada em pelo menos dois movimentos.

No primeiro movimento, discutimos o funcionamento das políticas linguísticas relacionadas ao processo de imigração (as quais incidem predominantemente sobre as línguas alemã e italiana), especificamente na década de 1930, quando, via "acontecimento histórico-discursivo"2 (Lei n. 1545/1939), foi oficialmente interditada a língua dos imigrantes e, entre outras medidas, por meio de campanhas de nacionalização, implantava-se a língua nacional, a língua portuguesa, nas áreas de colonização estrangeira, especialmente por meio de políticas que contemplavam a escola primária (PAYER, 1999). As consequências de tal acontecimento discursivo incidiram sobre todas as colônias de imigração e, sem ser exceção, também sobre a Quarta Colônia de Imigração Italiana no Rio Grande do $\mathrm{Sul}^{3}$. Já o segundo movimento abarca as ações desenvolvidas na região Oeste da Santa Catarina - especialmente pela Universidade Federal da Fronteira Sul (UFFS) - voltadas aos imigrantes hai-

que o acontecimento não é um fato no tempo: ele é que instala sua própria temporalidade, e o sujeito, por sua vez, é tomado pela temporalidade do acontecimento; quanto ao espaço, tomamo-lo enquanto espaço de enunciação, uma prática política, sendo que "falar" é assumir a palavra num espaço dividido de línguas e falantes, sendo isso uma obediência e/ou uma disputa, ainda conforme o autor (idem).

2 Cf. Zandwais, 2007, p. 253.

3 Com base na tese de doutoramento de Viviane T. B. Brust, em andamento, intitulada "O 'sertão' Quarta Colônia: travessias pelo imaginário de um sujeito imigrante” e em relação à dissertação de mestrado, de mesma autoria, finalizada em 2013 e intitulada "O efeito chapéu de Clementis: imagens do sujeito imigrante na Quarta Colônia”, ambas sob a orientação da Profa. Dr. Verli Petri. 
tianos ${ }^{4}$ que se instalaram no local após o terremoto que vitimou seu país de origem, no ano de 2010, no intuito de compreender a ação do Estado por meio de políticas linguísticas voltadas a essa parcela da população. Neste estudo, tomamos como base, o programa PROHAITI, buscando entender se ele pode ser considerado como uma política linguística.

\section{Entre o político e a(s) política(s)}

Compreendendo a língua em sua materialidade substancialmente política e distanciando-nos do efeito de evidência construído em torno da nomeação política, a qual, ancorada no discurso da democracia, pressupóe a existência de uma suposta atmosfera de consenso, pensamos o político na língua como o espaço de falhas e de disjunçóes. Orlandi (1998, p. 73) nos diz que o político, "[...] compreendido discursivamente, significa que o sentido é sempre dividido, sendo que esta divisão tem uma direção que não é indiferente às injunçôes das relaçóes de força que derivam da forma da sociedade na história”. Nesse sentido, o efeito de consenso, de unidade, gerado pelo regime democrático, é ilusório, uma vez que sempre há algo que foge e rompe com o controle. $\mathrm{O}$ consenso seria, então, um apagamento do político, da divisão e da disjunção próprios do dizer. Essa evidência de unidade é produzida, portanto, num processo ideológico de naturalização dos sentidos, que passa pela dispersão de sentidos no interdiscurso. A partir da leitura de política para Rancière (1996 [1995]) e das consideraçóes de Orlandi (1998) acerca do político, compreendemos melhor as articulaçóes entre essas noçóes, buscando problematizar suas imbricações na tríade língua, política e história, o que nos permitirá encontrar um caminho para compreender em que se constituem as políticas linguísticas.

E é Orlandi quem explicita como se dá a constituição de uma formação social em relação a essa busca de uma unidade própria. Em nosso entendimento, os dois movimentos de imigração observados neste texto deixam emergir efeitos da busca de um "desejado consenso". O espaço de enunciação, tanto dos imigrantes italianos (e alemães) do século XIX quanto dos imigrantes haitianos neste século XXI, é dado, pré-estabelecido, restrito, formatado, controlado. Espaço de enunciação esse que, conforme Guimarães (2005, p. 18), é constituído

4 Movimento que parte do projeto inicial da tese de doutoramento de Liana C. Giachini, em desenvolvimento, sob orientação da Profa Dr. Amanda Eloina Scherer. 
"politicamente pela equivocidade própria do acontecimento: da deontologia que organiza e distribui papéis, e do conflito, indissociado desta deontologia, que redivide o sensível, os papéis sociais". É nesse espaço de enunciação que, atravessado o efeito de evidência da política, compreendemos "a ilusão de apagamento de profundas disparidades que não são ditas" (ORLANDI, 2012, p. 28).

Ao pensarmos o político atrelado à língua, somos afetados pelo que nos diz Orlandi (2012, p. 29) em relação a essa produção de diluição e indistinção na busca pelo UM, que constitui a "nova língua de madeira da época moderna", como a forma de - no interior da língua - negar o político. Compreendemos, assim, que as línguas são afetadas, em seu funcionamento, por condiçóes de produção sócio-históricas específicas, em espaços de enunciação específicos. Importante destacarmos que, simultaneamente à concepção do político como inscrito na língua, há uma noção mais específica, "política de línguas" ou "política linguística", empregada pela Análise de Discurso. Essas formas, tratadas por Orlandi (2002) praticamente como sinônimos, designam decisóes técnicas, decretos legislativos, processos institucionais evidentes ou implícitos do Estado em relação às línguas faladas em seu território e nos remetem à noção de língua de madeira trabalhada por Gadet e Pêcheux, em $A$ lingua inatingivel (2004). Trata-se da "política de denegar a política: espaço do artifício e da dupla linguagem, linguagem de classe dotada de senha e na qual para 'bom entendedor' meia palavra basta. A língua do direito é uma língua de madeira" (GADET; PÊCHEUX, 2004, p. 24).

$\mathrm{Na}$ concepçáo discursiva, compreendemos que as políticas de língua estáo sempre em relação ao político, tentando afirmar ou apagar seu funcionamento, o que nos faz pensar que náo há uma dicotomia entre as duas noçóes, pois também na política linguística o político da língua está em funcionamento. Considerando, ainda, que o político se dê pela divisão, a política linguística nasce do imaginário de uma língua ideal ${ }^{5}$ e homogênea, do "desejo irrealizável de curar a ferida narcísica aberta pelo conhecimento da divisão" (PÊCHEUX; GADET, 2004, p. 19). Essa língua é a língua que, ao mesmo tempo em que se relaciona, se funde e se tenciona com a língua fluida ${ }^{6}$, a qual também tem

5 “[...] são as línguas-sistemas, normas, coerçôes, as línguas instituiçōes, a-históricas. É a sistematização que faz com que elas percam a fluidez e se fixem em línguas imaginárias" (ORLANDI; SOUZA, 1988, p. 28).

6 "A língua fluida é a que pode ser observada e reconhecida quando focalizamos os processos 
regras, mas mantém em sua a diversidade. Nesse sentido, há a pertinência de se considerar onde, quando e como tais políticas são geridas, gerenciadas, em que se trabalha conjuntamente com um outro imaginário, o de pertencimento: pertencer a uma nação, pertencer a um mundo globalizado, ou deixar de pertencer à "parcela dos sem parcela", conforme o dizer de Rancière (1996 [1995], p. 24). Segundo Barrios (2009, p. 25), "purismo, nacionalismo e imperialismo linguísticos adquieren mayor o menor relevância y visibilidade según las circustancias del contexto histórico em que se inscriben (consolidación de impérios o estados nacionales, expansión colonial, integración regional, etc.)", sendo que estão vinculados entre si. No entanto, a diversidade linguística tem sido contemplada em múltiplos documentos públicos, dentro de um quadro de diversidade cultural e social, exatamente pelo atual contexto. Para Barrios (2009), enquanto na União Europeia as minorias linguísticas são objeto de uma tutela especial, em função de fazerem parte do patrimônio histórico dos países em que estão radicadas, o Tratado do MERCOSUL "se centra en las lenguas oficiales de los países membros más que em las minorias linguísticas, pero más o menos paralelamente se han desarrollado acciones que contemplan las lenguas indígenas, también em termos de patrimônio" (BARRIOS, 2009, p. 26). Quanto à língua dos imigrantes, Barrios (2009) afirma que hoje, no atual contexto de globalizaçáo, quando os movimentos migratórios crescem a par de sua visibilidade midiática e afetam os países europeus mais desenvolvidos - e, acrescentamos, também países emergentes, como o Brasil -, "los inmigrante se han transformado em la 'piedra en el zapato' del discurso politicamente correcto de los derechos linguísticos y el respeto por la diversidade” (BARRIOS, 2009, p. 27).

Pagotto (2007, p. 35), por sua vez, afirma que a implementação de políticas ${ }^{7}$ linguísticas obedece a dois tipos de ações: ações de força por parte

discursivos, através da história da constituição de formas e sentidos, tomando os textos como unidade (significativas) de produção" (ORLANDI; SOUZA, 1988, p. 34).

7 Para compreendermos o funcionamento das políticas linguísticas, faz-se necessário definirmos algumas categorias em relação à língua. Nesse intuito, tomamos de empréstimo noçóes trazidas por Guimarães (2003, p. 48), que define a língua materna como a língua que os falantes praticam pelo fato de a sociedade em que nasceram praticá-la, constituindo-se para eles como a primeira língua e a língua nacional como a língua que caracteriza um povo, conferindo a seus falantes uma relação de pertencimento a este povo, e a língua oficial é a "língua de um Estado", obrigatória nas açôes formais e atos legais. 
do Estado para reafirmar a própria existência e açóes voltadas a atender demandas de grupos ou setores da sociedade, voltadas para o pluralismo. Com relação ao primeiro caso, podemos exemplificar com a interdição do idioma dos imigrantes na ditadura brasileira de Vargas (1930), em que a língua nacional se contrapóe à língua materna dos imigrantes, buscando um efeito de homogeneização, e o segundo caso pode ser verificado no ensino das línguas indígenas em algumas regiōes específicas do Brasil, o que pode também ser estendido às políticas destinadas aos imigrantes haitianos hoje, quando são implementados alguns projetos de ensino de língua portuguesa, sob a justificativa de inclusão social.

Consideramos que, salvaguardando o que distancia os dois processos migratórios, ambos os grupos, antes de sua chegada ao Brasil, já provêm de um espaço enunciativo marcado pela disputa, cujas fronteiras não se caracterizam por serem geográficas (embora a Itália, naquele momento, passasse pelo processo de Unificação, inclusive no que tange à língua), mas historicamente constituídas. Sujeitos que, dentro dos próprios países, constituem-se entrelínguas e entrelugares. Lugares que agora também são outros, constituídos pelo processo de migração. Lugares esses que o corpo-língua habita, carregando, dentro de si, as fronteiras imaginárias desse espaço enunciativo que se constitui entre movências do corpo (migração) e da língua (sua/do outro). Ao pensarmos em lugar, consideramos importante retomarmos as reflexóes de Scherer (2008, p. 132), para quem o sujeito pode ocupar diferentes lugares: "os lugares topológicos, os lugares na ordem da essência, e depois, há o lugar no mundo”. É nesse espaço entrelugares: topológicos, da ordem da essência e do mundo, que observamos o sujeito que adentra o Brasil, que é uma terra, uma cultura, uma língua. Esse sujeito que chega (e chega para ficar!) é o sujeito entrelínguas (para além do sujeito que habita espaços de regióes fronteiriças), pois o processo de imigração carrega em si mesmo a perda de territórios que vão além de marcaçôes geográficas. Esse sujeito entrelínguas só pode estar entrelugares, uma vez que, conforme Fonseca (2001), lugares não produzem sentidos ou identidade únicos, não têm limites precisos e abarcam conflitos internos. Diante das circunstâncias históricas em que tais sujeitos se inscrevem/se inscreveram, questionamos: quais políticas linguísticas têm dado conta de inseri-los na nova realidade social? 


\section{Condições de produção 1: “onde será essa américa?”}

Com base em Iotti (2010), sabemos que as condiçôes de produção em que se efetivou o processo de emigração-imigração de italianos para o Brasil deram-se dentro dos fenômenos migratórios que, em fins do século XIX e no início do século XX, movimentou milhares de europeus em direção à América, num processo histórico intrinsecamente ligado ao capitalismo. $\mathrm{Na}$ Itália recém unificada, os camponeses foram expulsos da terra, o artesanato foi parcialmente destruído e a indústria mostrou-se incapaz de absorver a mão de obra disponível. Foram 24 milhóes de peninsulares que saíram do país entre 1869 e 1962, sendo que se tornou um dos maiores exportadores de máo de obra barata do século XIX. Negócio do Estado, que encontrou, por essa via e outras dela decorrentes, uma forma de reequilíbrio socioeconômico do país (IOTTI, 2010). No Brasil, o fortalecimento do fluxo imigratório, sobretudo, o italiano, ocorreu no período de 1874 a 1889 , como alternativa ao trabalho escravizado, ligado à cafeicultura, principalmente no estado de São Paulo, mas foi disputado e reorientado à colonização territorial do Sul do País. No Rio Grande do Sul, os imigrantes vieram atraídos pelo sonho da terra, sendo que as três primeiras colônias foram Conde D’Eu (Garibaldi), Dona Isabel (Bento Gonçalves) e Caxias; em 1877, foi organizada uma quarta colônia, Silveira Martins, em terras na regiáo central do estado.

Quanto à questáo da língua, há que se considerar que a unificaçấo, o nascimento do Estado unitário italiano era fato recente - finalizado em 1870 - e, naquele território, viviam populaçóes diferentes, que falavam línguas diferentes. Nesse sentido, os imigrantes náo representavam um grupo homogêneo, e, em seus processos de identificação, não se consideravam italianos e sim vênetos, trentinos, friulanos, entre outros. Considerando que é "impossível que imigrantes tivessem vindo sem suas línguas, estrangeiras" (PAYER, 2001, p. 236), introduziu-se, assim, uma materialidade simbólica, indesejável, com a qual o Estado Brasileiro teria que lidar, dada a proporção de seus falantes, ou seja, um sujeito e sua língua, em seu modo específico de inscrição histórica e de existência material.

Payer (2006) expóe que, aqui, no Brasil, desde a década de 1920, já havia projetos educacionais pensados por intelectuais liberais que visavam à nacionalização, preocupados que estavam, principalmente, com a economia, 
uma vez que planejavam a reconstrução e o desenvolvimento nacionais. Tal projeto, nacionalista e liberal, previa envolvimento do Estado com a educação, o que foi levado até o governo Vargas, quando, então, foram tomadas medidas de reestruturação educacional, sendo que foram contemplados o ensino superior, a organização do secundário e o ensino comercial, não se incluindo a educação primária e a alfabetização. Mesmo em 1932, no Manifesto dos Pioneiros da Escola Nova, não houve ênfase na alfabetização. É na Constituição de 1934 que a educação primária passa a ser considerada, quando, então, passa a ser instituída pelo Estado, sendo integral, gratuita e de frequência obrigatória. Porém, na Constituição de 1937, dar-se-á atenção especial ao ensino primário, sobretudo, nas regiōes de imigração. Está-se sob a égide do Estado Novo (1937-1945), momento em que se proclama a "unidade nacional", são fechadas as Assembleias Estaduais e há intervenção nos Estados. Trata-se de um projeto político de construção de um processo identitário, sob um imaginário de unidade nacional, por uma "consciência nacional", o qual vai determinar uma história com reflexos subsequentes, o que continua a ser discursivizado ainda hoje, conforme afirma Zandwais (2007).

Diante disso, ser estrangeiro ou ser filho de estrangeiro, no Brasil do Estado Novo, é estar sob a ordem de medidas político-jurídicas que vão dispor sobre a segurança nacional e as condiçóes de cidadania. Assim, antes mesmo de se ter uma política de línguas endereçada aos imigrantes e aos seus, há um lugar a ele destinado pelo Estado, via decreto-lei n. $1545 / 1939^{8}$ que versa, no decorrer de seus artigos, sobre medidas de segurança específicas, uma vez que esse sujeito poderia estar simbolizando uma ameaça à soberania nacional, dada a situação de entre guerras e de ascensão do nazi-fascismo. Assim, temos o "informar ao Conselho de Segurança Nacional" qualquer medida adotada em relação à emigração no país, além de remeter relatórios a esse conselho com entradas e localização de estrangeiros; o evitar a aglomeração de imigrantes de uma mesma origem em um só Estado ou região; o proceder à incorporação no exército do maior número possível de filhos de estrangeiros, preferencialmente fora das regióes de suas habitaçóes; fiscalizar as zonas de colonização, fazer inspeçóes secretas, exercer vigilância em agentes estrangeiros, entre outras. Como afirma Zandwais (2007, p. 256), isso se projeta como "um mecanismo de

8 Disponível em: <http://www2.camara.leg.br/legin/fed/declei/1930-1939/decreto-lei-1545-25-agosto-1939-411654-publicacaooriginal-1-pe.html>. Acesso em: nov. 2015. 
violência capaz de forjar o mito de que a construção da 'identidade nacional' de um povo se efetiva pela destruição da diferença”, o que é reforçado pelo policiamento e pela punição de servidores que não cumprem tais ordens, o que consta nos artigos $8^{\circ}$ e $19^{\circ}$ da mesma lei, além do que institui um caráter xenofóbico em relação a esses estrangeiros, questão essa marcadamente contraditória, conforme aponta Zandwais (2012, p. 56), pois ao lado do promover a cidadania, temos o vigiar suas práticas e, quando do previsto infringir a lei, o punir por isso.

É para o sujeito que ocupa "esse lugar", de quem está, por sua diversidade e pelo que pode ideologicamente significar, ameaçando o país, que estarão sendo dirigidas as seguintes medidas legislativas, culturais e educacionais, dentro do decreto-lei n. 1545/1939, artigo 4º. Destacamos alguns recortes discursivos (RDs) como parte de nosso procedimento analítico, os quais incidem diretamente sobre questóes culturais e educacionais e, portanto, sobre a língua. Os destaques em negrito são nossos, pois, com base neles, procederemos às nossas análises.

RD1: medidas legislativas culturais e educacionais - decreto-lei n. 1545/1939, Art. $4^{\circ}$

Art. $4^{\circ}$ Incumbe ao Ministério da Educação e Saúde:

a) promover, nas regiôes onde preponderam descendentes de estrangeiros, e em proporção adequada, a criação de escolas que serão confiadas a professores que seráo capazes de servir aos fins desta lei." [...]

b) subvencionar as escolas primárias de núcleos coloniais, criadas por sua iniciativa nos Estados ou Municípios; favorecer as escolas primárias e secundárias fundadas por brasileiros;

c) orientar o preparo e o recrutamento de professores para as escolas primárias dos núcleos coloniais;

e) exercer vigilância sobre o ensino de línguas e da história e geografia do Brasil;

Fonte: BRASIL. Decreto-Lei no 1.545 , de 25 de Agosto de $1939^{9}$.

9 Disponível em: <http://www2.camara.leg.br/legin/fed/declei/1930-1939/decreto-lei-1545-25-agosto-1939-411654-publicacaooriginal-1-pe.html. Acesso em 29 nov. 2015. 


\section{RD2: Artigos 15 e 16 do Decreto-Lei 1545/1939}

Art. 15. É proibido o uso de línguas estrangeiras nas repartiçóes públicas, no recinto das casernas e durante o serviço militar.

Art. 16. Sem prejuízo do exercício público e livre do culto, as prédicas religiosas deverão ser feitas na língua nacional.

Fonte: BRASIL. Decreto-Lei no 1.545 , de 25 de Agosto de $1939^{10}$.

Compreendemos, por esses recortes, algumas situações, porquanto todas elas ligadas por um viés de violência simbólica. Em outras palavras, mesmo que a questão ideológica não seja homogênea, mesmo que sua condição econômica e social de imigrante já o coloque a serviço do Estado - o que, numa primeira instância, dentro das relaçóes de produção, estaria ao lado do trabalho e não do capital -, aquilo que lhe conferiria identidade e história, a língua, passa a ser a matéria simbólica pela qual vigora o poder autoritário que não aceita a diversidade linguística. $\mathrm{O}$ ensino, assim, coaduna-se com essas concepçóes, sendo que o que pauta as leis orgânicas reguladoras dos ensinos primário e secundário têm como seus eixos norteadores a educação patriótica, a formação de uma consciência patriótica e, principalmente, o conhecimento "seguro" da própria língua, como elemento cultural e como um próprio da existência da nação.

Importa destacar que, com relação aos haitianos, não há uma preocupação do governo com ações ou políticas de língua que se insiram na Educação Básica, como acontecia com os imigrantes italianos no Estado Novo. Para compreender essa diferença, a seguir, procuramos abordar em que condiçóes de produção se dá a vinda desses imigrantes para o Oeste Catarinense, para, então, procedermos à nossa análise.

\section{Condições de produção 2: “o haiti não é aqui”(?)}

O Haiti ocupa a $163^{a}$ posição entre 182 naçóes no ranking de Desenvolvimento Humano (2014). Conforme Pacífico e Pinheiro (2013), tal condição é reflexo de uma atribulada história política e econômica, marcada por suces-

10 Idem à nota anterior. 
sivos golpes de Estado na década de 1980, eleições livres e governo transitório nos anos 1990 e, após a violenta guerra civil de 2004, pela criação da Missão das Nações Unidas para a estabilização do Haiti, comandada pelo Brasil e instituída pela Resolução 1.542 do Conselho de Segurança da ONU.

Essa situação foi agravada, quando, em janeiro de 2010, o país foi acometido por um violento terremoto de grau 7,3 na escala Richter, que vitimou mais de 1,7 milhóes de pessoas, das quais aproximadamente 200 mil vieram a falecer. Os sobreviventes passaram, então, a habitar acampamentos provisórios, sem saneamento básico, acesso à água potável ou rede de esgoto. Assim, muitos haitianos foram obrigados a migrar para outros países em busca de melhores condições de vida e um dos destinos escolhidos por esses imigrantes foi o Brasil.

Télémaque (2012, p. 44) relata que a maioria dos haitianos chega ao país por rotas ilegais, fato que dificulta a longa viagem. Conforme o autor, normalmente as viagens duram aproximadamente três meses pela América do Sul, antes de entrar pela fronteira norte do país, por trajetos fluviais ou terrestres, e passando por Panamá, Equador, países que não exigem vistos para haitianos, e Peru, onde o visto se tornou obrigatório a partir de janeiro de 2012.

Em Santa Catarina, na Região Sul do Brasil, uma das cidades que mais recebeu haitianos foi Chapecó. Filipin e Zenni (2014) apontam que a maioria dos imigrantes haitianos que chega a essa região é constituída por homens entre os 20 e 30 anos, com escolaridade entre ensino fundamental e médio. Contudo, mesmo com a baixa escolaridade, as autoras chamam atenção para o fato de que grande parte desses imigrantes fala mais de quatro línguas e, em seu estudo, defendem a necessidade de políticas públicas voltadas à recepção e manutenção dos migrados, uma vez que constataram a inexistência de políticas relacionadas a esse grupo social.

Com relação às políticas linguísticas não é diferente. As políticas linguísticas voltadas aos imigrantes se reduzem a açóes isoladas, promovidas por instituiçóes de ensino, como a Universidade Federal da Fronteira Sul, e empresas que oferecem cursos de instrumentalizaçáo para o trabalho. Na região Oeste de Santa Catarina, especificamente em Chapecó, identificamos a existência do programa PROHAITI (Resolução n. 32/2013), da Universidade Federal da Fronteira Sul, que oferece aos imigrantes haitianos vagas suplementares no ensino superior. Iniciado em 2013 , o projeto possibilitou o ingresso, por meio 
de processo seletivo especial, de cerca de 40 alunos, em cursos como Administração, Agronomia, Ciência da Computação, História, Letras Português e Espanhol, Pedagogia e Geografia. Além do acesso ao ensino superior, o PROHAITI busca desenvolver açóes voltadas ao imigrante haitiano, como se pode verificar no recorte abaixo, retirado do Portal da UFFS.

\section{RD3: Ações desenvolvidas pelo PROHAITI}

O programa PROHAITI tem realizado diversas açóes que colaboram com a integração desses imigrantes:

- - Inserção dos grupos de cidadãos haitianos nas atividades culturais promovidas na Universidade;

- - Acolhimento aos alunos que vieram morar em Chapecó para estudar na UFFS;

- - Organizaçáo de um grupo de servidores voluntários para aulas de português básico; (grifo nosso)

- - Validação de diplomas e históricos escolares junto a Embaixada do Haiti em Brasília;

- - Promoção de atividades voltadas às necessidades da comunidade haitiana vinculada à Universidade;

- - Organização de evento valorizando a cultura haitiana visando à integração e a troca de conhecimento entre os acadêmicos estrangeiros e brasileiros.

- - Realização do $1^{\circ}$ Diálogo com Mulheres Imigrantes sobre Saúde Feminina: Cuidados e Prevenção

Fonte: UFFS ${ }^{11}$.

Em nosso ver, ainda que ambos os movimentos imigratórios analisados ocorram em meio ao capitalismo, no caso dos haitianos, ocorre em tempos de globalização ${ }^{12}$. Isso interfere nas condiçóes históricas, que determinam também as políticas públicas de imigração, uma vez que, conforme Santos (1994, p. 48), o espaço geográfico é uma funcionalização da globalização e será pro-

11 Disponível em: <http://www.uffs.edu.br/index.php?site=uffs\&option=com_content\&vi ew $=$ article $\& \mathrm{id}=6465$ : acoes $\&$ catid $=416$ :aai-paginas $\& I t e m i d=2256>$. Acesso em: 29 nov. 2015.

12 “O espaço se globaliza, mas não é mundial como um todo senão como metáfora. Todos os lugares são mundiais mas não há um espaço mundial. Quem se globaliza mesmo são as pessoas" (Milton Santos, 1993). 
duzido conforme as demandas de quem o idealizar, para que possa suprir suas necessidades. Segundo o autor, o espaço geográfico funciona, então, como um "conjunto indissociável de sistemas de objetos naturais ou fabricados e de sistemas de açôes, deliberadas ou não" (1994, p. 49). Nesse sentido, a globalização e a consequente reconfiguração do cenário econômico mundial, que (re) organizam as fronteiras e rotas de imigração, gera a necessidade de diferentes políticas para dar conta desse novo imigrante.

Ao invés de políticas que abarquem o ensino fundamental e médio e que "nacionalizem" a língua dos filhos dos imigrantes italianos e alemães, que trouxeram as famílias em busca de uma utópica América (por exemplo), a sociedade precisa, agora, inserir no mercado de trabalho homens e mulheres adultos solteiros (ou que deixaram as famílias no país de origem), que vêm em busca de sobrevivência e encontram um Brasil não mais agrário, mas em desenvolvimento, cuja indústria precisa de mão de obra para funcionar. $\mathrm{O}$ programa PROHAITI se constitui, assim, como uma tentativa de instrumentalizar esses trabalhadores e prepará-los para o exercício da cidadania brasileira, numa nova ordem, em que o discurso de inclusão passa a constituir um imaginário de naçáo permeado pela contradição. $\mathrm{Na}$ sequência, passamos a discutir o funcionamento desse imaginário de cidadão brasileiro nos dois momentos analisados.

\section{Língua e cidadania: do efeito de pertencimento}

Rancière (1996, p. 44) nos diz que o caráter político de uma ação não é constituído por seu objeto ou pelo lugar onde é exercida, mas unicamente por sua forma, "a que inscreve a averiguação da igualdade na instituição de um litígio, de uma comunidade que existe apenas pela divisão”. É com relação a isso, portanto, que pensamos o objeto de nossa análise neste texto.

Com relação à política de línguas na Ditadura Vargas (1937-1945), o que primeiro precisa ser referido é que se trata de um Decreto-Lei, ou seja, "decreto com força de lei emanado do poder executivo, quando este acumula anormalmente as funçôes do legislativo", segundo Houaiss (2009), o que já dá o caráter contextualmente "inquestionável”, antidemocrático do referido ato. Tal decreto tem como explicação dispor "sobre a adaptação ao meio nacional dos brasileiros descendentes de estrangeiros”, mas não legisla somente sobre 
esses, pois, para ilustrar, no artigo $8^{\circ}$, consta no inciso a) "evitar a aglomeração de imigrantes de uma mesma origem [...]”.

Mas visamos a nos deter no Art. $4^{\circ}$. No inciso a) temos o promover a criação de escolas, sendo que essas "serão confiadas a professores capazes de servir aos fins desta lei" "13, ou seja, promover a criação de escolas não imprime um caráter de compromisso efetivo do Estado com a criação de escolas. Diante disso, uma outra contradição se estabelece: ao lado da obrigatoriedade, o Estado não assegura, na proporção que exige, essa instrução. Além disso, conforme nos relata Payer (2006), no segmento de uma prática da instrução básica desenvolvida pela própria população de imigrantes, nos âmbitos familiar e depois comunitário, em sua língua, até o final da década de 1930 e início da de 1940, decorrente da ausência de escolas, passando pelos projetos e pelas campanhas implementadas pelo Estado Novo, a disponibilidade de professores "capazes de servir aos fins desta lei” fica, igualmente, comprometida. Tais questóes são reafirmadas nos incisos b), quando o uso do verbo "subvencionar" se abre tanto para o papel de o Estado dar efetivamente subsídio quanto para uma atitude de prestar auxílio, ajudar, socorrer, prover, conforme Houaiss (2009); o uso do verbo "favorecer", por sua vez, implica tomar partido de; proteger, apadrinhar; ou seja, pressupóe uma divisão, desigual e desigual também nas suas "escolhas"; nessas ocorrências, podemos observar uma relação que remete ao “ 'pai dos pobres', frase bíblica (Livro de Jó - 29:16), e título criado pelo seu Departamento de Imprensa e Propaganda (DIP)”, conforme Brust (2004, p. 52), o qual atesta o caráter populista e de culto à personalidade do entáo ditador-presidente. $\mathrm{Na}$ alínea $\mathrm{c}$ ), entendemos que "orientar" o preparo não é o mesmo que oferecer formação aos professores e que "recrutamento" advém, por nossa memória discursiva, da linguagem militar, significando convocar, alistar, arrebanhar, conforme Houaiss (2009), imaginário que não se coaduna com o papel e o lugar de professor. Quando, na alínea e), nos deparamos com a questão do exercício da vigilância, entendemos, na prática social, o que Rancière (1996 [1995], p. 14) distingue de política e de polícia, uma vez que não se entende/se estende a esse período a questão da democracia e de suas práticas, apenas aquilo "que se pratica e se diz sob o nome de fim da política ou de seu retorno, o que se exalta sob o nome de humanidade sem fronteira

13 BRASIL. Decreto-Lei no 1.545 , de 25 de Agosto de 1939. Fonte: idem à nota 12. 
e se deplora sob o reino do desumano". Isso será reiterado nos Artigos 15 e 16 do referido Decreto-Lei, marcando, pela proibição do uso da língua de imigrantes nos espaços representativos dos Aparelhos do Estado, conforme Althusser (1975 [1969), a fronteira entre poder e não poder, entre o poder e o não-poder, sob o efeito de que se tornem "cidadãos".

Entendemos o paradoxo da tomada de posição do Governo Vargas com sua política linguística: ao mesmo tempo que visava a "incluir" o estrangeiro dentro de um espaço identitário nacional, e isso por meio da imposição da língua nacional brasileira (em contraposição a suas línguas maternas, estabelecendo aí uma zona de litígio), tal questão esteve envolta na intolerância com a diversidade, na violência simbólica. Além disso, considerando mesmo os seus próprios propósitos, estes não foram "eficientes" em atender com escolas e com ensino todas as regióes de imigrantes.

Dessa forma, a apropriação ou não da língua nacional, ao mesmo tempo em que se tem a proibição da língua materna, continua sendo, por todas as vias, a forma com a qual o imigrante e seus descendentes continuam circunscritos ao lugar de não inclusão. Desses lugares destinados ao sujeito imigrante do século XIX e XX, de pertencimento ou não à nação brasileira pela apropriação da língua nacional, podemos pensar que, entre o não estar mais na sua língua materna e o ainda não estar na língua nacional brasileira, esteve o sujeito a que nos referimos, nesse dado real histórico, num entrelugar, lugar de entremeio, à deriva, à procura de seu lugar simbólico. É essa a instância que se instala na memória discursiva do e sobre o sujeito imigrante italiano no século passado, na instância em que o político das políticas linguísticas atravessa as práticas sociais, dividindo sujeitos e sentidos.

Tais consideraçóes tomam o sujeito imigrante (e seus descendentes) da/ na Quarta Colônia, inicialmente porque esteve "fronteirizado" no espaço geográfico e histórico da Quarta Colônia, de Imigração, no Rio Grande do Sul, no Brasil, ou seja, esteve dentro e esteve fora: não mais na língua italiana, em sua diversidade, não ainda na língua portuguesa, mesmo com suas singularidades; não mais na Itália, mas numa colônia, italiana, que é no Brasil. Depois, porque estar no referido lugar é estar num real da história e num imaginário de memória: sempre nos entremeios, em limites, tensionados de apagamentos, saturações, de injunçóes, em que, sim, há um político (mediando?) e uma política vencedora - hoje, mesmo que a língua portuguesa carregue a (carregue 
na) memória da língua italiana, é nela (e por ela) que se dá o elo de pertencer à cidadania brasileira.

Cabe referir, no entanto, que se esse foi o efeito/a consequência da já referida política de Vargas, hoje, em função de termos outras condições de produção em funcionamento, outra relação política do Estado com a diversidade, um outro acontecimento discursivo (re)simboliza o sujeito imigrante italiano na língua: a inclusão do "Talian”, língua dos imigrantes italianos, no Inventário Nacional de Diversidade Linguística, em setembro de 2014, pelo Ministério da Cultura, como "Referência Cultural Brasileira" ${ }^{4}$. Tal inventário, conforme consta no art. $1^{\circ}$ do Decreto 7387 de 09 de dezembro de 2010, é considerado "como instrumento de identificação, documentação, reconhecimento e valorização das línguas portadoras de referência à identidade, à ação e à memória dos diferentes grupos formadores da sociedade brasileira" ${ }^{15}$. Diante disso, consideramos interessante buscar compreender como os sentidos que relacionam a língua portuguesa ao pertencimento à cidadania brasileira continuam funcionando, mesmo em distintas condiçóes de produção.

Entendemos que o PROHAITI, bem como a maioria dos programas voltados à Língua Portuguesa para imigrantes hoje, tem estreita relação com o mercado de trabalho ou com a capacitação para o ingresso no ensino superior, e se fundam no "uso da língua como língua de referência, de trabalho e como condição de acesso à cidadania” (Silva, 2013, p. 298). Observamos que as línguas em funcionamento nesse processo discursivo de constituição da identidade e cidadania desse imigrante são relacionadas a funçôes historicamente constituídas, em um espaço de disjunção e litígio no qual a busca pela unidade não é capaz de calar a contradição própria da língua. Entendemos que esse efeito de unidade e consenso entra em funcionamento no sistema democrático de forma imaginária, uma vez que no real não há o Um. Como bem nos aponta Rancière (1996 [1995]), essa lógica do consenso é a negação do político e, nesse processo de "produção imaginária do consenso por políticas públicas produz, ao contrário, e contrariamente, a segregação" (ORLANDI, 2012, p. 26), posto que não suporta a contradição que lhe é própria, constitutiva mesmo.

14 Disponível em: <http://portal.iphan.gov.br/pagina/detalhes/183/>. Acesso em: fev. 2016.

15 Disponível em: <http://www.planalto.gov.br/ccivil_03/_Ato2007-2010/2010/Decreto/ D7387.htm>. Acesso em: fev. 2016. 
Esse efeito de apagamento das diferenças sócio-históricas foi procurado tanto na relação com o imigrante europeu quanto em relação ao imigrante haitiano; porém, se em relação ao primeiro não tivemos $\backslash$ um discurso de valorização das especificidades linguísticas e culturais, em relação ao segundo, tem-se, mesmo que atravessado pelo imaginário da língua nacional "aparatada pelo Estado para ser a língua oficial” (ORLANDI, 2007, p. 60). O imigrante haitiano - assim como fora o imigrante italiano - é recebido no país com direitos e deveres, mas, para que possa se constituir como cidadão, deve fazê-lo por meio da Língua Portuguesa. Quando pensamos em açôes voltadas ao ensino da Língua Portuguesa para esse sujeito imigrante haitiano, indagamos as questóes políticas relacionadas a essas práticas. $\mathrm{O}$ aprender a língua do Estado está na ordem do dever, uma vez que se torna pré-requisito para a assunção da posição sujeito cidadão. Assim, conforme assinala Pfeiffer (2000, p. 28) "Dever poder passa a funcionar como dever, dívida, falta (grifos da autora)".

Compreendemos, então, "as sutilezas" de Estado para diluir o diferente no interior do mesmo e que há um efeito de interdição da língua materna que entra em funcionamento na constituição do sujeito imigrante haitiano, ainda que não exista uma política declarada de proibição por parte do Estado. Não há uma lei específica, como o decreto-lei n. 1545/1939, relacionado aos imigrantes europeus, mas se busca a identidade nacional por meio de mecanismos ideológicos que fazem funcionar esse ideário de cidadania brasileira por meio da língua dos aparatos jurídicos, a língua oficial - a língua portuguesa, que pode tanto incluir quanto excluir. Isso porque "[...] quando se define que língua falamos, com que estatuto ou quando se determina este ou aquele modo de acesso a esta língua - pelo ensino, pela produção dos instrumentos lingüísticos, [...] - praticamos concomitantemente diferentes formas de política de língua" (ORLANDI, 2010, p. 35-36). Nas relações com o Estado, com o mercado de trabalho, a única língua possível é a língua portuguesa, a língua oficial, aparatada para oferecer o acesso ao trabalho, à saúde e cuja proficiência lhe permite gozar dos direitos do cidadáo imigrante. Nesse sentido, nesse espaço de enunciação do imigrante haitiano no Brasil, o acesso à palavra é submetido à divisão pela disputa entre as línguas e seu lugar de prestígio ou marginalidade. Mais do que isso, essas relaçóes são reguladas pela divisão interna das línguas, que distribui de modo desigual o direito ao dizer, divisão 
essa que é própria do político na língua. Consideramos importante ressaltar o fato de que essa divisão na/pela língua é constitutiva do sujeito. Contudo, em nossa análise, essa negociação/imposição da língua tem especificidades históricas que devem ser levadas em conta ao se pensar esse sujeito em sua relação com a aquisição de uma nova língua outra.

Isso porque esse sujeito imigrante haitiano tem na língua a materialização do conflito de classes, a representação de processos históricos, uma vez que o Haiti é um país marcado pela diglossia ${ }^{16}$, fruto da conturbada história política, que se marca também pela/na língua. Ao migrar para o Brasil, esse sujeito já sempre entrelínguas haitiano entra em contato com a Língua Portuguesa necessária para o pertencimento, para a sobrevivência, para o fazer parte, o ter direito a, e deve se submeter a uma nova língua oficial - do Estado brasileiro - para significar numa língua do papel, que atesta a permanência e a sobrevivência nesse processo de (re)territorialização.

\section{Considerações finais}

Neste texto, procuramos discutir a noção de política de língua, pensando também no funcionamento do político na/pela língua em torno do sujeito imigrante, italiano nos séculos XIX e XX, e haitiano, no século XXI. Ao pensarmos o Programa PROHAITI como uma iniciativa da Universidade Federal da Fronteira Sul, em parceria com a embaixada do Haiti no Brasil, tendo como "objetivo contribuir para integrar os imigrantes haitianos à sociedade local e nacional, por meio do acesso aos cursos de graduação da UFFS, e qualificar profissionais que ao retornar possam contribuir com o desenvolvimento do Haiti" 17 , consideramos que, embora no documento esteja prevista a inclusão de atividades relativas ao aprendizado da Língua Portuguesa, não podemos tomá-lo como uma política linguística de Estado em relação à imposiçáo de uma língua e à interdição de outra, devido ao caráter local que assume. Além disso, não há um decreto/lei, como no caso dos imigrantes italianos, que interdita sua língua materna. Nesse sentido, compreendemos

16 Diglossia é uma situação linguística relativamente estável em que, junto aos dialetos primários da língua, há um dialeto muito divergente, altamente codificado, sobrepondo-se à variedade (FERGUSON, 1959, p. 435).

17 Resolução no 32/2013 (CONSUNI, p. 1). 
as ações descritas nos recortes analisados como práticas específicas, que buscam sentidos de integração do imigrante haitiano na realidade institucional, em que a língua funciona como mecanismo de acesso à cidadania por meio do saber institucionalizado. Contudo, conforme apontamos anteriormente, essa língua que não é imposta por uma política de interdição é a mesma que é exigida pela estrutura econômica do mercado de trabalho e pelos órgãos oficiais, aos quais cabe o poder de conferir o estatuto de cidadão a esse sujeito em processo de (re)constituição identitária.

Entendemos que as implicações do político na língua se dão no processo de negociação de sentidos atrelados à busca pelo pertencimento, de um sujeito errante, desterritorializado, à deriva. Entendemos também, em função das políticas linguísticas empreendidas pelo Estado, como esse se configura: totalitário ou democrático, na forma como se relaciona com as massas, mantendo a desigualdade, privando-lhes dos direitos ou desfazendo os nós do desentendimento, conforme conceitua Rancière (1996 [1995]), exemplificado, esse último, em seu efeito, com a língua dos imigrantes italianos: mesmo que reconhecida, é reconhecida tardiamente - pois esta funciona hoje mais como uma língua na/da memória - e o é pelo Ministério da Cultura, não da Educação, o que teria outras implicaçóes.

E aqui nos apoiamos novamente nas ideias de Rancière (1996 [1995], p. 54) quando argumenta que "a política não é feita de relaçóes de poder, é feita de relaçóes de mundos”. E que mundos? Que lugares são esses? Lugares onde o político se dá pela contradição, lugares do dizer e do calar, que ultrapassam as fronteiras do dentro/fora num movimento da ordem do sem fim, que pode ser representado pela banda de moebius ${ }^{18}$. Consideramos que o político atravessa esse espaço de enunciação, em que a divisão se materializa também na/pela língua num processo de (re)produção dos embates ideológicos, "um modo de partilha que torna a própria partilha invisível, uma vez que os excluídos são tornados inaudíveis" (RUBY, 2009, p. 61, apud MARQUES; LELO, 2014, p. 55).

18 De acordo com Ferreira (2003, ap. oral), a Banda de Moebius, "mostra a impossibilidade de se estabelecer os limites entre o avesso e o direito, entre o interno e o externo, já que cada lado representa essas duas faces ao mesmo tempo, acabando com a dicotomia habitual de separar os fatos que são da língua e os que são extra-lingüísticos”. 


\section{Referências}

ALTHUSSER, L. Aparelhos Ideológicos de Estado: nota sobre os aparelhos ideológicos de Estado (AIE). Traduzido por Maria Laura V. de Castro. Introdução crítica de José Augusto Albuquerque. 2. ed. Rio de Janeiro: Graal, 1985 [1969]. p. 53-107.

BARRIOS, Graciela. El tratamento de la diversidade linguística em el Debate Educativo: paradigmas teóricos, representaciones y políticas linguísticas. In: Anais do IV Encontro Internacional de Pesquisadores de Politicas Linguisticas. Santa Maria, 21 a 24 de Setembro de 2009. (Mesa Redonda). UFSM/Associação de Universidades Grupo Montevidéu. Santa Maria: Sociedade Vicente Palotti, 2009.

BRUST, Viviane T. B. De língua e de línguas: slogans políticos e ideologias de governo. Revista Escrita, PUC-Rio, n. 19, 2014.

FERGUSON, C. A. Diglossia. Word, 15, april, Journal of linguiistic, 1959.

FERREIRA, M. C. L. A língua da análise de discurso: esse estranho objeto de desejo. In: Seminário de Estudos em Análise do Discurso, 1. Anais... Porto Alegre: UFRGS, 2003. (Comunicação oral). Disponível em: <http://www. ufrgs.br/analisedodiscurso/anaisdosead/1SEAD/Paineis/MariaCristinaLeandroFerreira.pdf>. Acesso em: 10 out. 2014.

FILIPIN, E. ZENNI, K. Migração haitiana para o Brasil: acolhimento e políticas públicas. In: Revista Pretexto. Vol. 15. N. 2. Abr/jun. p. 11-27. Belo Horizonte: 2014.

FONSECA, Antonio Angelo Martins. A emergência do Lugar no contexto da globalização. Revista De Desenvolvimento Econômico. Salvador, Ano III, n.5, p. 96-103, dez.-2001.

GADET, Françoise; PÊCHEUX, Michel. A lingua de Marte. In: GADET, Françoise; PÊCHEUX, Michel. A lingua inatingivel: o discurso na história da linguística. Trad. Bethania Mariani e Maria E. C. de Mello. Campinas, SP: Pontes, 2004, p. 19-26.

GUIMARÁES, Eduardo. Semântica do Acontecimento: um estudo enunciativo da designação. Campinas: Pontes, 2005.

GUIMARAES, E. Enunciação e política de línguas no Brasil. In: Revista Letras, no 27, Dezembro 2003. Disponível em: http://cascavel.ufsm.br/revistas/ ojs-2.2.2/index. php/letras/article/viewFile/11897/7319. Acesso em: 4 out 2015. 
GUIMARÁES, E. Textualidade e enunciação. In: Escritos, no 2. Disponível em: http://www.labeurb.unicamp.br/portal/pages/pdf/escritos/Escritos2.pdf. Acesso em 31 mai 2016.

HOUAISS, Antônio. Dicionário eletrônico Houaiss da língua portuguesa. Rio de Janeiro, RJ: Objetiva, 2009.

INDURSKY, Freda (orgs.). Análise de discurso no Brasil: mapeando conceitos, confrontando limites. São Carlos, SP: Claraluz, 2007.

IOTTI, Luiza Horn. Imigração e poder: a palavra oficial sobre os imigrantes italianos no Rio Grande do Sul (1875-1914). Caxias do Sul, RS: EDUCS, 2010.

ORLANDI, Eni Puccinelli. Análise de discurso: princípios e procedimentos. 9a Edição, Campinas-SP, Pontes Editores, 2010.

- Teoria da linguagem e discurso do multilinguismo na contemporaneidade. In: Politica Linguistica no Brasil. Orlandi. E. P. (org)/ Campinas, SP: Pontes Editores, 2007.

- O Discurso sobre a língua no periodo Vargas (Estado Novo 1937/1945). In: Linguas e instrumentos linguisticos. N. 15. Pontes Editores e Projeto História das Ideias Linguísticas. Campinas, SP, 2005.

. (org). Politica Lingüística no Brasil. Campinas, SP: Pontes, 2007.

ORLANDI, Eni Pulccinelli. Lingua e conhecimento linguistico. São Paulo, SP: Cortez, 2002.

ORLANDI, E. P.; SOUZA, T. C. C. A língua imaginária e a língua fluida: dois métodos de trabalho com a linguagem. In: ORLANDI, E. P. Politica lingüistica na América Latina. Campinas: Pontes, 1988.

NAÇÓES UNIDAS. 2011. Índice de Desenvolvimento Humano. Human Development

Report. Disponível em: <http://hdr.undp.org/en/media/HDR_2011_EN_ Summary.pdf $>$. Último acesso em: 20 Out. 2012.

PACÍFICO, A. PINHEIRO, K. O status do imigrante haitiano no Brasil após o terremoto de 2010 sob a perspectiva do Pós-Estruturalismo. In: Revista Perspectivas do Desenvolvimento. Disponível em: http://periodicos.unb. br/index.php/ perspectivas dodesenvolvimento/article/view/9837. Acesso em 19 ag 2015.

PFEIFER, C. C. Bem dizer e retórica: um lugar para o sujeito. 2000. Tese (Doutorado) Unicamp, Campinas. 2000. 
PAYER, M. O. Memória da língua: imigração e nacionalidade. São Paulo: Escuta, 2006.

SCHERER, Amanda Eloina. Dos domínios e das fronteiras: o lugar fora do lugar em outro e mesmo lugar. In: SARGENTINI, Vanice; GREGOLIN, Maria do Rosário (orgs.). Análise do discurso: heranças, métodos e objetos. São Carlos: Claraluz, 2008.

TÉLÉMAQUE, J. 2012. Imigração haitiana na mídia brasileira: Entre fatos e representaçóes. Rio de Janeiro, UFRJ/ECO. Disponível em:

$<$ http://oestrangeirodotorg.files.wordpress.com/2012/08/jenny-haitianos-mono.pdf>.

Último acesso em: 04 Out. 2012.

RANCIÈRE, Jacques. (1995) O desentendimento: política e filosofia. Tradução de Ângela Leite Lopes. São Paulo: Ed. 34, 1996 [1995].

RODRIGUES, Luiz Carlos Balga. Francês, crioulo e vodu: a relação entre língua e religião no Haiti. Orientador: Pierre François Georges Guisan. Rio de Janeiro: UFRJ, 2008. Tese (Doutorado em Estudos Lingüísticos Neolatinos - Língua Francesa).

RUBY, Christian. L'interruption: Jacques Rancière et la politique. Paris: La Fabrique, 2009. In: MARQUES, A. C. S. , LELO, T.V. Aspectos poéticos-comunicacionais da filosofia politica de Rancière a partir dos conceitos de dano, dissenso e desidentificação. Intexto, Porto Alegre, UFRGS, n. 31, p. 52-67, dez. 2014.

SANTOS, Milton. A aceleração contemporânea. In: SANTOS, Milton et al. (Orgs.). O novo mapa do mundo. São Paulo: Hucitec, 1993.

SANTOS, Milton. Técnica, espaço, tempo: globalização e meio técnico-científico internacional. São Paulo: Hucitec, 1994.

ZANDWAIS, Ana. Saberes sobre a identidade nacional: o processo de construção de um imaginário de cidadania durante o governo Vargas. In: FERREIRA, Maria C. L.; INDURSKY, Freda (orgs.). Análise de discurso no Brasil: mapeando conceitos, confrontando limites. São Carlos, SP: Claraluz, 2007. 
IN THE SEARCH OF AMERICAS, ESCAPING THE HAITIS, THE IMMIGRANT SUBJECT IN LANGUAGE

ABSTRACT: In this text we attempt to reflect about the political as constitutive of language, connecting it to the notion of linguistic policies. Such issues are thought of in linguistic policies destined to immigrant subjects, as well as to their effects in different production conditions: in relation to the nineteenth and twentieth century Italian immigrants during the Vargas Dictatorship, and to the Hatian immigrants, in the twenty-first century, when there are both democracy and globalization.

KEYWORDS: language policy; immigrant subject; immigration languages

Recebido em: 09/07/2016 Aprovado em: 18/10/2016 